\title{
Different Class Citizens: Understanding the Relationship between Socio-economic Inequality and Voting Abstention
}

\author{
TAMARA EHS AND MARTINA ZANDONELLA
}

\section{sciendo}

Politics in Central Europe (ISSN: 1801-3422)

Vol. 17, No. 3

DOI: 10.2478/pce-2021-0022

\begin{abstract}
In most established democracies the turnout gap along class lines has increased substantially since the 1980s. Political participation has become a question of resources: income, property, formal education, secure employment and overall social status determine citizens' engagement in political decision-making. Using a mixed methods approach, our case-study shows that this also applies to Vienna - an overall rich city with a long tradition of social reform policies, often credited with the highest quality of life in the world. Although Vienna still has a relatively high turnout by international standards, political participation is very unevenly distributed once socio-economic resources are taken into account. Thereby and throughout life, class shapes people's experiences with and as part of democracy. These experiences in turn have long-term effects on their trust in the political system and on their political self-efficacy. Our findings first and foremost contribute to the ongoing debate on democracy's social imbalance and show that its consequences already apply on the regional level. The study additionally highlights the usefulness of mixed methods approaches when we aim at a better understanding of the class-based turnout gap.
\end{abstract}

Keywords: voter turnout, social inequality, participation, mixed methods design

1 The study was financed by three research grants, provided by (1) Vienna Chamber of Labour, (2) City of Vienna and (3) the iac of the Robert Bosch-Foundation. 


\section{Introduction}

The idea of democracy is based on equality of participation in decision-making. According to the democratic ideal, social status must be irrelevant when it comes to political participation. But in fact, a vast range of research has documented the uneven distribution of political participation along class lines. Furthermore, this turnout gap has increased substantially since the $1980 \mathrm{~s}$ - in many established democracies and often parallel to the rise of socio-economic inequality. Class impacts political participation (Armingeon - Schädel 2015; Barthels 2008; Schäfer et al. 2020) as well as party preference formation, both for voters (Kitschelt - Rehm 2014; Engler - Weisstanner 2020) and legislators (Carnes 2013). The growing, class-based participation gap is accompanied by distortions of political issue setting and decision-making, as democracies have become less responsive to the political concerns of the less affluent (Schäfer Schwander 2019). As wealthier citizens go to the polls more often and vote for political parties that continue to secure their relatively privileged position, their political concerns are eventually disproportionately represented in the democratic institutions. On the other hand, less affluent citizens more often abstain from voting and therefore do not have the same chances of having their needs implemented in the political process (Carnes 2013; Peters - Ensink 2015; Elsässer 2018).

One might object that, regarding universal suffrage, voting abstention is voluntary. However, this overlooks that although the decision for or against voting is made by the individual, they do not act independently of their relative position in society (Schäfer 2015). Here, the resource-theoretical approach of participation research meets the theory of relative power differences: Socio-economic inequality translates into political inequality because it discourages already disadvantaged groups from getting involved. And as political decisions in favour of those who participate oftentimes reinforce socio-economic inequality, the already disadvantaged are kept even further away from the polls (Epp Borghetto 2020; Gingrich - Häusermann 2015). The 'social question' therefore is crucial for the understanding of democracy's crises, currently displayed by a widening, class-based participation gap and a turn to populist as well as radical right-wing political parties. Regarding the latter, populists and the radical right became attractive for the distressed middle classes because they channel their perceived threat of decline and claim to restore their dignity. The upper classes support populists and the radical right - not only through voting, but much more efficiently through funding - to secure their wealth and power (Gidron Hall, 2017; Kurer - Palier 2019; Burgoon et al 2019; Engler - Weisstanner 2020). The lower classes, on the other hand, hardly find any connections with the party system and more and more abstain from voting (Rovny - Rovny 2017). Consequently, no effect of populist parties on voter turnout has been found so 
far (Schwander et al 2020). This supply-side gap (Hillen - Steiner 2020) again adds to the mechanisms that exclude the political positions of the lower classes from parliaments and governments (Rosset - Stecker 2019).

Obviously, distributional issues at various levels are at stake, but they no longer reach political decision-makers at a rate commensurate with rising inequality: In recent decades, economic inequalities between countries have indeed narrowed, but those within countries have widened. In poorer countries, the middle classes have been the main beneficiaries of strong economic growth. In richer countries, the trend has been different: The lower classes and the middle classes have seen their incomes stagnate or fall, while income and wealth of the upper classes has increased considerably (Alvaredo et al. 2017; Lakner - Milanovic 2016). The class-based participation gap therefore not only concerns democracies with traditionally higher economic inequality, like the USA or the UK (Dalton 2017), it increasingly affects European democracies with stronger redistribution policies and welfare states, such as Austria. Currently, these developments are further exacerbated by the Covid-19 pandemic.

The links between socio-economic inequality and political participation have been documented by numerous studies and seem well established. Our research contributes in two, so far underrepresented aspects. First, it serves as an in-depth case study for democracies with still relatively strong redistribution policies and welfare states. Second, it highlights important processes which tie socio-economic resources to political participation. We chose Vienna for our case study because we wanted to provide robust data for an already ongoing debate about the social imbalance of democracy during the run-up to the 2020 regional election. Beyond that, we wanted to contribute to already existing research by further advancing the understanding of the relationships between socio-economic resources and voting abstention.

Although Vienna holds the world's highest quality of living (Mercer 2019) and despite its hundred-year-old tradition of social reform policies (most notably in the field of social housing), considerable socio-economic inequalities exist and are reflected in voter turnout. Voting was never compulsory in Vienna's regional elections, but until the 1980s turnout always reached well above $70 \%$, frequently close to $80 \%$. With the deregulation of the labour market, the rise in unemployment, the dismantling of the welfare state and increasing economic inequality, voter turnout started to fall below the two-thirds mark and it fell unevenly across Vienna's 23 districts. Since the 1990s those districts with lower income, higher unemployment and higher poverty rates have the lowest turnout, whereas turnout is particularly high in the upper middle class and upper class districts. In the 2020 regional election, for example, the highest turnout reached $76 \%$ in one of the wealthiest districts. The lowest turnout, on the other hand, reached $59 \%$ in one of the districts with the least socio-economic resources. This imbalance is reinforced by the fact that in Vienna 
every second blue collar worker is not entitled to vote because he or she lacks Austrian citizenship. Additionally, the socio-economically better-off not only participate more frequently in elections, the same is true for all other instruments of democracy, like citizens' initiatives or party donations. Wealthier citizens therefore accumulate political capital through a lot of different and, considering party donations, powerful channels. Thus, Vienna is approaching the international trend of a 'two-thirds democracy' (Merkel - Petring 2011), in which the third with the least socio-economic resources increasingly refrains from political participation and is ultimately not represented within the political spectrum. The same is true for Austria as a whole: $83 \%$ of the upper third (classified along socio-economic resources) participated in the 2019 National Council election, but only $59 \%$ of the lower third (Zandonella 2019).

\section{Method and data}

To gain more information about Vienna's participation gap, its socio-economic foundations, and about different processes at work on the group - as well as on the individual - level, we decided on a mixed methods approach. This allowed us to not only include quantitative and qualitative components into our research, but also to connect and combine these components with each other. We worked with an explanatory sequential mixed method design (Creswell - Plano Clark 2006; Ivankova et al. 2006), generating structural data on a small-scale regional level (phase 1), conducting a representative survey (phase 2) and conducting biographical interviews (phase 3).

In the first phase of the study, we generated a dataset on the structural level. Starting from the already known association between socio-economic resources and turnout on the district level, we aimed for a smaller scale unit. As the districts are not only diverse between but also within each other, we assumed that the participation gap might be underestimated by looking at the districts alone. With the data available we finally intersected census districts and electoral districts to create a small-scale unit dataset, suitable for studying our research question and hypothesis. Census districts are subdivisions of each municipality and one of the smallest geographical reference units. Vienna is subdivided into 1,343 census districts and for each of these, various indicators of socio-economic inequality are available (number and share of women, age groups, citizenships, birth countries, formal education groups, unemployed and economic sectors, as well as the average annual net income of employees and pensioners). As census districts offer no information about voter turnout or election results, we had to incorporate electoral districts. Electoral districts are the smallest administrative unit enshrined in electoral law. They are designed to facilitate the electoral process, and are therefore divided according to the expected number of voters per hour. For the most recent National Council election (2019), Vienna 
was divided into 1,447 electoral districts. For each electoral district, turnout and election results for votes casted at polling stations are available. To assign the absentee votes, the absentee ballots were allocated proportionally to the electoral districts using the statistical procedures of SORA's absentee ballot forecast. As census and electoral districts can coincide, but do not have to, we generated a dataset based on census districts, including the mentioned indicators of socio-economic inequality as the most accurate information available for voter turnout. Using the geographic information system QGIS, the mean coordinate of each electoral district was specified and then integrated into the map of Vienna, already divided into census districts. For each census district, the mean turnout of those election districts, whose geographical centres lie within the census district, was calculated. The final dataset is based on census districts and includes the above-mentioned indicators of socio-economic inequality as well as the information on turnout. The data was analysed using the Spatial Durbin Error Model, a spatial econometrics variation of linear regression. This statistical procedure allows us to account for spatial autocorrelation, which might occur between small-scale neighbouring areas like census districts and distorts conventional regression coefficients (Elhorst 2010).

For the second phase of the study, we left the structural level and turned to the individual. Expanding our research scope, we now added data on people's attitudes and experiences related to democracy. Based on the findings of phase 1, we conducted a representative survey among 981 Viennese aged 16 and over, with 16 being the age at which one is entitled to vote in Austria since the electoral reform in 2007. (It's noteworthy that the city of Vienna had been a pioneer, having lowered the voting age to 16 already in 2002. This is therefore the fourth election since lowering the voting age). Telephone and web interviews were combined to reach all population groups. The sampling procedure was twofold. We first stratified along three socio-economic clusters, which were identified during the first phase of the study. Within each cluster, respondents were then selected randomly. Post-stratification weighting ensured a Viennese-representative sample. We developed a standardised questionnaire for the survey, including attitudes towards democracy, perceived responsiveness of the political system in Austria, political participation and socio-economic resources. Data analysis focused on the relationships between socio-economic resources, experiences, attitudes and non-voting, and was primarily conducted via logistic and linear regression as well as path models.

The third phase of the study aimed at a more comprehensive understanding of the indirect effects of socio-economic resources on non-voting, which were identified during phase two. To gather in-depth information about people's experiences with and as part of the democratic system, we conduct biographical interviews. These focused on political socialisation as well as on experiences with democratic institutions and political participation in various contexts. 
We selected our interviewees from the survey respondents, mainly choosing from census districts belonging to the cluster with the least socio-economic resources (theoretical sampling; Corbin - Strauss 2014). Due to the pandemic all interviews were conducted by telephone, and all followed the same interviewer's guide. We developed this guide to ensure thematic comparability across all interviews. Data analysis focused on how structural conditions and individual actions interact and followed a content analytical framework.

\section{Results}

Analyses on the structural level confirmed first of all that the participation gap widens considering small-scale units: While voter turnout in the 2019 National Council election differed by up to 15 percentage points between Vienna's 23 main districts, the difference between the census districts is up to 28 percentage points. Subsequently, spatial linear regression analysis shows that socio-economic resources are directly linked to turnout - the fewer resources accumulated in a census district, the fewer of its residents went to the polls. Relevant are both economic and cultural capital: Low average income and a high unemployment rate decrease turnout as well as a high share of residents with compulsory school-leaving certificate and a high share of residents working in jobs with low occupational prestige. The extent of their effects on turnout are considerable: If, for example, the unemployment rate in an average census district increases by one percentage point, voter turnout decreases by 0.5 percentage points. If, on the other hand, the average annual income in this district increases by 1,000 euros, voter turnout rises by one percentage point (keeping all other predictors equal).

In Vienna, too, socio-economic resources accumulate regionally. Cluster analysis, calculated with the significant indicators from the regression analysis above, points to three broad groups of census districts. Each of these groups is characterised by specific socio-economic conditions and corresponding electoral participation. Within the upper cluster, many economic resources, high social status and a high turnout come together. A particularly large number of academics reside in this cluster, in addition to high occupational prestige and high average income. The unemployment rate is low, while turnout came out well above the average. The census districts of this upper cluster are home to about 20 percent of Vienna's eligible voters.

Within the middle cluster we find - according to its name - socio-economic resources as well as turnout in line with Vienna's average. Slightly more than 40 percent of Vienna's eligible voters reside in these census districts. Within the lower cluster, few economic resources and low social status meet equally low turnout. More than one third of Vienna's eligible voters live in these neighbourhoods, characterised by low-status employment, a high unemployment 
Table 1: Spatial Durbin Error Regression Model on voter turnout

\begin{tabular}{|c|c|c|c|c|c|c|}
\hline & \multicolumn{2}{|c|}{ direct } & \multicolumn{2}{|c|}{ indirect (Lag) } & \multicolumn{2}{|c|}{ total } \\
\hline & $\beta$ & $\mathrm{p}$ & $\theta$ & $\mathrm{p}$ & B & $\mathrm{p}$ \\
\hline Proportion of women & $-0,089$ & 0,17 & $-0,024$ & 0,82 & $-0,113$ & 0,35 \\
\hline Proportion of pensioners & 0,017 & 0,47 & 0,083 & 0,09 & 0,100 & 0,11 \\
\hline Proportion Austrian citizens & 0,006 & 0,77 & 0,001 & 0,97 & 0,007 & 0,87 \\
\hline Proportion Turkisch citizens & 0,252 & 0,08 & 0,157 & 0,53 & 0,409 & 0,15 \\
\hline Proportion citizens of former Yugoslavia & 0,123 & 0,12 & 0,203 & 0,16 & 0,326 & 0,11 \\
\hline Proportion university graduates & 0,178 & 0,00 & 0,032 & 0,17 & 0,210 & 0,00 \\
\hline Proportion comuplsory school & $-0,373$ & 0,00 & $-0,181$ & 0,05 & $-0,554$ & 0,00 \\
\hline Unemployment rate & $-0,346$ & 0,00 & $-0,119$ & 0,24 & $-0,465$ & 0,00 \\
\hline Annual net income & 0,001 & 0,00 & 0,000 & 0,08 & 0,001 & 0,00 \\
\hline constant & & & & & 98,925 & 0,00 \\
\hline
\end{tabular}

Reported are linear regression coefficients (direct, indirect and total effects)

Coefficients in bold indicate significant effects $(p<0,05)$

rate and low average income. A particularly large number of residents work in occupations labelled as system-relevant throughout the pandemic: cleaning staff, nursing staff and caregivers, delivery staff, construction workers or grocery store employees. Their work is poorly paid, little valued and their working conditions are poor (Schoenherr - Zandonella 2020). Not surprisingly at this point, turnout in the lower cluster came out far below Vienna's average. In addition, significantly fewer residents of the lower cluster are eligible to vote because of

\section{Table 2: Three socio-economic clusters}

\begin{tabular}{|l|c|c|c|c|c|c|c|c|}
\hline cluster & $\begin{array}{c}\text { propor- } \\
\text { tion of } \\
\text { elegible } \\
\text { voters }\end{array}$ & $\begin{array}{c}\text { average } \\
\text { annual } \\
\text { net in- } \\
\text { come* }\end{array}$ & $\begin{array}{c}\text { un- } \\
\text { employ- } \\
\text { ment } \\
\text { rate }\end{array}$ & $\begin{array}{c}\text { propor- } \\
\text { tion com- } \\
\text { pulsory } \\
\text { school }\end{array}$ & $\begin{array}{c}\text { pro- } \\
\text { portion } \\
\text { universtiy } \\
\text { graduates }\end{array}$ & $\begin{array}{c}\text { proporti- } \\
\text { on lower } \\
\text { occupa- } \\
\text { tional } \\
\text { prestige }\end{array}$ & $\begin{array}{c}\text { proporti- } \\
\text { on non- } \\
\text {-Austrian } \\
\text { citizens }\end{array}$ & $\begin{array}{c}\text { turnout } \\
(2019 \\
\text { National } \\
\text { Council } \\
\text { election) }\end{array}$ \\
\hline upper & $20 \%$ & 30778 & $6 \%$ & $13 \%$ & $38 \%$ & $30 \%$ & $23 \%$ & $81 \%$ \\
\hline middle & $43 \%$ & 24139 & $10 \%$ & $21 \%$ & $22 \%$ & $44 \%$ & $25 \%$ & $72 \%$ \\
\hline lower & $37 \%$ & 18541 & $18 \%$ & $35 \%$ & $12 \%$ & $59 \%$ & $38 \%$ & $64 \%$ \\
\hline
\end{tabular}

* income tax liable income (employees and pensioners) in Euro 
foreign citizenships. Taking together the low turnout and the high rate of non-eligibles in the lower cluster, only 40 percent of its residents are represented within the institutions of representative democracy. Thus, political inequality based on socio-economic resources further increases in these neighbourhoods by excluding foreign citizens from the right to vote.

Leaving the structural level and turning to the results of our representative survey, we first of all can conclude that structural socio-economic inequality, subsumed in the clusters presented, reflects itself in the perceptions of the respondents who live in those areas. While most residents of the lower cluster assign themselves to the lower and working classes, the vast majority of the residents of the upper cluster view themselves as part of the upper middle and upper classes. This subjective social positioning is closely linked to socio-economic resources on the one hand, and to social recognition on the other. Concerning the latter, about half of the employees living within the lower cluster state that their work is not valued by society (comparted to 16 percent of employees within the upper cluster). As already mentioned, many of them work in low paid jobs with poor working conditions like cleaning, caregiving, delivery or retail. Logistic regression analysis indicates that this lack of social recognition, together with fewer socio-economic resources, strongly affects individual electoral participation: Low financial means in the form of income and property, unemployment, lower levels of formal education and a subjectively lower position within society go hand in hand with a lower propensity to vote in the then upcoming regional elections. The combined impact of these effects is illustrated by the following examples. Academics with incomes in the top-third, who additionally own property or other considerable financial reserves, and who place themselves within the upper ranks of society, have a 98 percent chance of voting in the upcoming election. Unemployed skilled workers, on the other hand, without financial reserves but still average income and who identify as working class, have a 51 percent chance of voting. If their unemployment lasts and income gradually falls below the poverty line, their chance of participating in an upcoming election drops further to a mere 30 percent.

This link between socio-economic resources, social recognition and voting is mediated by trust in the political system and its perceived responsiveness: For nearly two-thirds of the residents in the lower cluster, the political system in Austria does not work well (the same applies to one-fifth of the residents in the upper cluster). To make matters worse, the majority of people with low financial resources (64 percent) and the majority of those who identify as working class (74 percent) report that politicians treat them like second-class citizens. Many then lack confidence in the effectiveness of political participation - 60 percent of people with low financial resources and $66 \%$ of those who identify as working class are convinced to have no influence on any kind of political decision-making, because their voices are not heard or do not count. 
Table 3: Logistic Regression Model on planned participation in the upcoming election

\begin{tabular}{|c|c|c|c|}
\hline & B & $\mathrm{p}$ & $\operatorname{Exp}(B)$ \\
\hline women & 0,239 & 0,13 & 1,270 \\
\hline age 60plus & 0,098 & 0,65 & 1,103 \\
\hline migrational background & $-1,010$ & 0,03 & 0,364 \\
\hline citizenship & $-1,374$ & 0,00 & 0,253 \\
\hline formal education & 0,754 & 0,00 & 2,125 \\
\hline household income & 0,723 & 0,00 & 2,061 \\
\hline property & 0,403 & 0,03 & 1,496 \\
\hline unemployment & $-1,048$ & 0,00 & 0,351 \\
\hline subjective class position & 0,385 & 0,00 & 1,470 \\
\hline constant & 0,959 & 0,00 & 2,609 \\
\hline
\end{tabular}

Reported are logit coefficients

Coefficients in bold indicate significant effects $(p<0,05)$

Following on from this, the qualitative interviews we conducted during the final phase of our study provide insight into the conditions under which trust in the political system and political efficacy emerge. While both are strongly based on the experiences people have with and as part of the democratic system, these experiences highly depend on one's socio-economic situation. Tracing the meso- and micro-level of Verba et al.'s (1995) Civic Voluntarism Model, we took a closer look at the political socialisation of our interviewees.

At the beginning of each electoral biography, there are significant others who convey the importance, usefulness or simply self-evidence to vote. Thereby, democracy-learning has at least three aspects: On the cognitive level, knowledge is passed on; on the emotional level, voting is established as the deep-felt core of democracy; and on the behavioural level, the act of voting is rehearsed by repeatedly accompanying adults to the polling station. In terms of institutions, school plays an important role in political socialisation. At school, however, existing inequalities are perpetuated rather than compensated for. Civic and citizenship education reached our interviewees coming from well-off families directly. They not only learned (about) democracy, but also experienced themselves as an effective part of it early on at school. On the other hand, interviewees with poor or working class backgrounds felt hardly addressed by civic and citizenship education. School in fact instilled in them that democracy is something in which they are not meant to be a part: ${ }^{2}$

2 The following quotes from our interviews were translated from German to English by the authors. 
'At school, the lowering of voting age was discussed and there was also talk about upcoming elections. But I always thought that this was not about me, that I was not included. [...] My parents couldn't afford tutoring, so I didn't graduate in the end.'

What school had not provided for our poor and working class interviewees was repeatedly made up for at work. Democracy at the workplace therefore is not only important for political socialisation in general (Geurkink et al. 2020; Jian - Jeffres 2008; Carter 2006), it is specifically relevant for people with less socio-economic resources, as it oftentimes enables their first positive experiences with democracy and participation:

'Our instructor at work talked to us apprentices about the elections: what each party means for us as workers. I liked that and felt that politics has something to do with my life.'

'It was only during my apprenticeship that I learned, through conversations with colleagues, how Austrian politics work. Who stands for what and what democracy actually is.'

'Before my first national or regional election, I had already participated in works council elections.'

The older our survey respondents and our interviewees were, the more likely they belonged to a political camp or had family ties to a political party that obliged them to vote. This adds to recent studies showing that the 'start-up costs of voting' have risen along social status lines (Schäfer et al. 2020). While there had always been a certain difference in the probability of first-time voting related to individual or parental resources (Plutzer 2002), most Western European democracies could reduce this gap through the strong presence of Labour or Social Democratic Parties attached to the class cleavage. This changed throughout the 1990s, as these parties shifted their focus and policies ('third way'). We now witness an increasing and class-based participation gap among first-time voters - even in Vienna, where the voting age was already lowered to 16 in 2002, coming into effect for the 2005-election (Wagner et al. 2012). More than ever, (non-)voting is a 'social act' (Bhatti/Hansen 2012):

'There was no political education at school. What I know about politics, I know from my family and later through the Arbeiter-Zeitung.' [n.b.:"Workers' Newspaper" was the daily of the Social Democratic Party, published from 1889 till 1991]

'Everyone around me voted for the Social Democrats. So I did that, too. I never thought about voting for anyone else.' 
'I am 78 years old and have always voted for the Social Democrats - without any doubt, because I grew up in a socialist household.'

'As a Social Democrat, you vote: Count heads, don't bash heads! I fight at the ballot box.'

On the other hand, our non-voting interviewees with low socio-economic resources expressed extremely low levels of trust in state institutions, politics, political parties and in the effectiveness of their own vote. This lack of trust is the result of multiple, partly lifelong experiences of exclusion. The political system has so far denied them participation in economic security, social recognition and in shaping their own living conditions. Within this context, especially strong negative impacts arise from degrading and humiliating experiences with welfare institutions and authorities. All of this leads to the conclusion that political participation is fake because the existing system, its representatives and their supporters are not interested in any kind of change:

'I can't do much with politics. When I was a child, my family had to disclose everything to the job center, the youth welfare, the social welfare - answering the most intimate questions, adults treated like little kids. To this day I am afraid of state authorities.'

'I've been to the polls once or twice so far, but I don't see the point. Nothing changes for me. I will not take part in the Vienna election; elections have nothing to do with me and my life - for me, life always remains the same struggle.'

'I've thought about going to the polling station with my kids. But I don't want to teach them that voting changes anything. That is an illusion.'

'I would vote again - if someone came along and convinced me that my participation actually made sense.'

\section{Discussion}

Our study provides useful indications for researching and understanding the crises of democracy, especially when it comes to the relation between socio-economic inequality and political participation already at the regional level. There are potential limitations: The study was designed as an in-depth case study, referencing Austria's capital. Even though its basic assumptions and main results confirm findings from other country or cross-country-studies, further research is needed to examine whether its results are generalisable in more detail. We are therefore planning further studies of other Austrian regional 
elections as well as a comparison of municipal elections in Central Europe and invite readers researching Central European cities to contact us for research collaboration.

The key message of our study is: Socio-economic resources determine people's experiences within the political system; these experiences shape their trust in democracy and their political efficacy, and eventually determine their political participation. Thereby, regional socio-economic inequality is strongly reflected in the perceptions and living conditions of the residents and does leave its mark on their attitudes towards the political system and their political participation. Within this context, the resulting sense of injustice might be a source from which political participation emerges. However, this does not apply to the residents in the cluster with the least socio-economic resources, as they lack a prerequisite for turning their sense of injustice into political action: the conviction that political participation actually can make a difference. This conviction, or the lack of it, is based on the totality of experiences people make within the democratic system. The nature of these experiences, in turn, is shaped by their socio-economic situation. For people with fewer resources, this first of all means being constantly denied participation in financial security and social recognition: Their jobs are poorly paid, their working conditions are hard and appreciation for their work is low. Although the pandemic brought attention to the system-relevance of many of these jobs, this so far has changed nothing for the people doing them. Maldistribution and misrecognition - the two kinds of obstacles to participatory parity Nancy Fraser (2007) identified - clash in the lower classes. For people with fewer socio-economic resources democracy more often than not means lifelong financial struggle and exposure to access discrimination, degradation and contempt. Particularly harmful for the trust in democracy and for political participation are humiliating experiences within state institutions. Here, the affective aspects of class inequality (Skeggs 1997) and their role in class formation become most obvious. Hence, our study also adds insights into how maldistribution and misrecognition create different class citizens.

Alas, the right to vote is not only to be understood formally: It is not sufficient for the democratic claim that people are endowed with equal participation rights. Rather, the preconditions for participation must also be equally distributed. This first and foremost means socio-economic resources, respectively their redistribution. Based on that, all sorts of social grievances (Castel 2009) must be considered. As those arise primarily from lack of recognition in a downwardly mobile society (Nachtwey 2016), they are not only central for voting abstention, but also for the formation of party preferences.

In Vienna, too, the class gap translates into a turnout gap - on the individual as well as on the structural level. As wealthier citizens and wealthier neighbourhoods become disproportionally represented in parliaments, policies preferring 
their concerns follow (Elsässer 2018). This, in turn, fosters already existing experiences of not being represented and of political powerlessness among the lower classes. Within this context, abstention from voting might in fact appear as a rational choice.

Finally, from a methodological point of view, the mixed methods design proofed useful for gaining a broader and deeper understanding of the relationships between socio-economic inequality and voting abstention. Within that approach, the introduction of geographic information systems into electoral research not only allowed the spatial localisation and analysis of socio-economic inequality and turnout, but the visualisation of these inequalities also turned out to be broadly accessible and lead to lasting impressions among politicians, civil servants, trade unionists and journalists, which whom we have so far discussed the main results and implications of this study. Studies like these therefore also contribute to an evidence-based public debate on the social imbalance of democracy.

\section{References}

Alvaredo Facundo - Chancel, Lucas - Piketty, Thomas - Saez, Emmanuel - Zucman, Gabriel (2017): Global inequality dynamics: New findings from WID.world, in: American Economic Review 107/5, pp. 404-409.

Armingeon, Klaus - Schädel, Lisa (2015): Social Inequality in Political Participation: The Dark Sides of Individualisation, in: West European Politics 38/1, pp. 1-27.

Bartels, Larry (2008) Unequal Democracy: The Political Economy of the New Gilded Age, Princeton.

Bhatti, Yosef - Hansen, Kasper M. (2012): Leaving the Nest and the Social Act of Voting: Turnout among First-Time Voters, in: Journal of Elections, Public Opinion and Parties 22(4), pp. 380-406.

Burgoon, Brian - van Noort, Sam - Rooduijn, Matthijs / Underhill, Geoffrey (2019): Positional deprivation and support for radical right and radical left parties, in: Economic Policy 34/97, pp. 49-93.

Carnes, Nicholas (2013): White-Collar Government: The Hidden Role of Class in Economic Policy Making, Chicago.

Carter, Neil (2006): Political Participation and the Workplace: The Spillover Thesis Revisited, in: The British Journal of Politics - International Relations 8, pp. 410-426.

Castel, Robert (2009:) Die Wiederkehr der sozialen Unsicherheit, in: Castel, Robert / Dörre, Klaus (eds) Prekarität, Abstieg, Ausgrenzung. Die soziale Frage am Beginn des 21. Jahrhunderts, Frankfurt am Main / New York, pp. 21-34.

Corbin, Juliet - Strauss, Anselm (2014): Basics of qualitative research: Techniques and procedures for developing grounded theory, Thousand Oaks. 
Creswell, John - Plano Clark, Vicky (2006): Designing and Conducting Mixed Methods Research, Thousand Oaks.

Dalton, Russell J. (2017): The Participation Gap. Social Status and Political Inequality, Oxford.

Elhorst, Paul (2010): Applied Spatial Econometrics: Raising the Bar, in: Spatial Econometric Analysis 5/1, pp. 9-28.

Elsässer, Lea (2018): Wessen Stimme zählt? Soziale und politische Ungleichheit in Deutschland, Frankfurt a. M./New York.

Engler, Sarah / Weisstanner, David (2020): The threat of social decline: income inequality and radical right support, in: Journal of European Public Policy https://doi.org/10.1080/13501763 .2020.1733636.

Epp, Derek - Borghetto, Enrico (2020): Legislative agendas during periods of inequality: evidence from Europe and the United States, in: Journal of European Public Policy, https://doi.org/10 $.1080 / 13501763.2020 .1734060$.

Fraser, Nancy (2007): Re-framing justice in a globalized world, in: Terry Lovell (ed.) (Mis)recognition, social inequality and social justice: Nancy Fraser and Pierre Bourdieu, Abingdon, pp. 17-35.

Geurkink, Bram - Akkerman, Agnes - Sluiter, Roderick (2020): Political Participation and Workplace Voice: The Spillover of Suppression by Supervisors, in: Political Studies https://doi. org/10.1177\%2F0032321720960969.

Gidron, Noam / Hall, Peter (2017): The Politics of Social Status: Economic and Cultural Roots of the Populist Right, in: British Journal of Sociology 68/S1, pp. 57-84.

Gingrich Jane - Häusermann, Silja (2015): The decline of the working-class vote, the reconfiguration of the welfare support coalition and consequences for the welfare state, in: Journal of European Social Policy 25/1, pp. 50-75.

Hillen, Sven - Steiner, Nils (2020): The consequences of supply gaps in two-dimensional policy spaces for voter turnout and political support: The case of economically left-wing and culturally right-wing citizens in Western Europe, in: European Journal of Political Research 59/2, pp. 331-353.

Ivankova, Nataliya -Creswell, John - Stick, Sheldon (2006): Using mixed-methods sequential explanatory design: From theory to practice.

Jian, Guowei - Jeffres, Leo (2008): Spanning the Boundaries of Work: Workplace Participation, Political Efficacy, and Political Involvement, in: Communication Studies 59, pp. 35-50.

Kitschelt, Herbert - Rehm, Philipp (2014): Occupations as a Site of Political Preference Formation, in: Comparative Political Studies 47/12, pp. 1670-1706.

Kurer, Thomas - Palier, Bruno (2019): Shrinking and Shouting: The Political Revolt of the Declining Middle in Times of Employment Polarization, in: Research - Politics 6/1.

Lakner, Christoph - Milanovic, Branko (2016): Global income distribution: From the fall of the Berlin Wall to the great recession, in: World Bank Economic Review 30, pp. 203-232.

Mercer (2019): Quality of Living index. Available at: https://www.mercer.com/newsroom/2019quality-of-living-survey.html. 
Merkel, Wolfgang - Petring, Alexander (2011) Auf dem Weg zur Zweidrittel-Demokratie: Wege aus der Partizipationskrise, in: WZB-Mitteilungen 134, pp. 30-33.

Nachtwey, Oliver (2016): Die Abstiegsgesellschaft. Über das Aufbegehren in der regressiven Moderne, Frankfurt am Main.

Peters, Yvette - Ensink, Sander J. (2015): Differential Responsiveness in Europe: The Effects of Preference Difference and Electoral Participation, in: West European Politics 38/3, pp. 577-600.

Plutzer, Eric (2002): Becoming a Habitual Voter: Inertia, Resources, and Growth in Young Adulthood, in: The American Political Science Review 96/1, pp. 41-56.

Rosset, Jan - Stecker, Christian (2019): How well are citizens represented by their governments? Issue congruence and inequality in Europe, in: European Political Science Review 11/2, pp. 145-160.

Rovny, Allison E. - Rovny, Jan (2017): Outsiders at the ballot box: operationalizations and political consequences of the insider-outsider dualism, in: Socio-Economic Review 15/1, pp. 161-185.

Schäfer, Armin - Roßteutscher, Sigrid - Abendschön, Simone (2020): Rising start-up costs of voting: political inequality among first-time voters, in: West European Politics 43/4, pp. 819-844.

Schäfer, Armin (2015): Der Verlust politischer Gleichheit. Warum die sinkende Wahlbeteiligung der Demokratie schadet, Frankfurt am Main.

Schäfer, Armin - Schwander, Hanna (2019): 'Don't play if you can't win': Does economic inequality undermine political equality? in: European Political Science Review 11/3, pp. 395-413.

Schoenherr, Daniel - Zandonella, Martina (2020): Arbeitsbedingungen und Berufsprestige von Beschäftigten in systemrelevanten Berufen in Österreich. Available at: https://www.arbeiterkammer.at/interessenvertretung/arbeitundsoziales/arbeits.

markt/AK_Studie_Arbeitsbedingungen_in_systemrelevanten_Berufen.pdf.

Schwander, Hanna - Gohla, Dominic - Schäfer, Armin (2020): Fighting Fire with Fire? Inequality, Populism and Voter Turnout, in: Politische Vierteljahresschrift 61, pp. 261-283.

Skeggs, Beverly (1997) Formations of class and gender, London.

Verba, Sidney - Schlozman, Kay - Brady, Henry (1995): Voice and Equality. Civic Voluntarism in American Politics, Harvard.

Wagner, Markus - Johann, David - Kritzinger, Sylvia (2012): Voting at 16: Turnout and the quality of vote choice, in: Electoral Studies 31/2, pp. 372-383.

Zandonella, Martina (2019): Österreichischer Demokratie Monitor 2019. Available at: https:// www.demokratiemonitor.at/wp content/uploads/2020/03/SORA-Bericht-Demokratie-Monitor-2019.pdf.

Tamara Ehs is a political scientist and consultant for democratic innovation. Currently, she works with Austrian municipalities to foster citizens' participation on the local level. She is a member of the advisory board to the European Capital of Democracy under the patronage of the Council of Europe as well as member of the Austrian 'Bürgerforum Europa' supporting the Conference on the Future of Europe. As her consultancy is based on scientific research she holds numerous academic co- 
-operations, especially with the Sigmund Freud University Vienna and the Robert Bosch Foundation (iac Berlin). Moreover, she is taking part in the COST-Action CA17135 on 'Constitution-making and Deliberative Democracy'. ORCID: https:// orcid.org/0000-0001-7660-8168; E-mail: tamara.ehs@univie.ac.at.

Martina Zandonella is a social scientist and senior researcher at SORA - Institute for Social Research and Consulting in Vienna. Her research focuses on democracy and participation, mainly within the context of social inequality, civic and citizenship education, and democracy at work. She is responsible for Austria's annual Democracy Monitor and is a member of the advisory board to the Vienna Forum for Democracy and Human Rights. E-mail: mz@sora.at. 